Asian J. Med. Biol. Res. 2019, 5 (1), 8-13; doi: 10.3329/ajmbr.v5i1.41039

\author{
Asian Journal of \\ Medical and Biological Research \\ ISSN 2411-4472 (Print) 2412-5571 (Online) \\ www.ebupress.com/journal/ajmbr
}

\title{
Article \\ Evaluation of ginger extract's yield, using cold extraction method and its antimicrobial activity against pathogens
}

\author{
Bikram Gautam $^{1,2^{*}}$, Richa Nepal ${ }^{1}$, Rupa Bhandari ${ }^{1}$ and Shishir Gyawali ${ }^{1}$ \\ ${ }^{1}$ Department of Microbiology, St. Xavier's College, Maitighar, Kathmandu, Nepal \\ ${ }^{2}$ Research Center for Applied Science and Technology, T.U., Kritipur, Nepal
}

*Corresponding author: Bikram Gautam, Department of Microbiology, St. Xavier's College, Maitighar, Kathmandu, Nepal. E-mail: gautambikr@gmail.com

Received: 07 June 2018/Accepted: 18 February 2019/ Published: 31 March 2019

\begin{abstract}
Ginger is commonly used herb across the world either in a meal or in herbal products. The chemical constituents of ginger possess antioxidants, can modulate apoptosis, inhibit vascular endothelial growth factor and inhibit inflammatory reactions. The main aim of this study is to assess the antimicrobial activity of the ginger extracts. For this purpose, ginger rhizome (R), packaged ginger powder $(\mathrm{P})$ and ginger leaves $(\mathrm{L})$ were collected from Urlabari, Morang and Kathmandu, Nepal. The plant materials were first minced (except P) and then extracted using cold extraction technique. For assessing the antimicrobial activity of the extracts against the American Type Culture Collection (ATCC) strains, cup well method was preferred. The percentage yield of extracts R, P, L and ginger rhizome's juice (J) was $10.79 \pm 0.03 \%, 9.76 \pm 0.16 \%, 8.17 \pm 0.07 \%$ and $16.8 \pm$ $1.98 \%$ respectively. The extract R were found to susceptible against the pathogens Streptococcus pneumoniae, Klebsiella pneumoniae, Escherichia coli, Staphylococcus aureus and methicillin resistant Staphylococcus aureus (MRSA). The extract P were found to susceptible against the pathogens E. coli, S. aureus and MRSA. The methanol extract of $\mathrm{L}$ was found to be susceptible to $S$. aureus, K. pneumoniae and MRSA. All the extracts $(\mathrm{R}, \mathrm{P}, \mathrm{L})$ were reistant against Pseudomonas aeruginosa. All 6 bacterial isolates were resistant against the extract J. The extract shows antimicrobial property only when the extract is concentrated. The ginger leaves also have antimicrobial property.
\end{abstract}

Keywords: ginger; extract; antimicrobial activity; yield

\section{Introduction}

Ginger (Zingiber officinale belongs to family Zingerberaceae) is a horizontal, branched, fleshy, aromatic white to yellow colored perennial herb with a leafy stem (Rahmani, 2014) up to $60 \mathrm{~cm}$ with narrow leaves (Malu et al., 2009) $20 \mathrm{~cm}$ long and $1.5-2 \mathrm{~cm}$ wide, has long been used in the field of medicine (Chan et al., 2008, Mashhadi et al., 2013). It is rich in phenolic compounds (gingerol, paradol and shogaol), volatile sesquiterpenes (zingiberene and bisabolene) and monoterpenoids (curcumin and citral) (Sagdic et al., 2003; Mashhadi et al., 2013; Rahmani, 2014; Kafeshani, 2015). Since ancient times ginger has been used all over the world as herb (Mashhadi et al., 2013), and even recently it has used for complications like diabetes (Mahluji et al., 2013; Mashhadi et al., 2013; Rahmani, 2014; Shidfar et al., 2015), cancer (Rhode et al., 2007; Chan et al., 2008; Mahluji et al., 2013; Mashhadi et al., 2013; Rahmani, 2014, Riaz et al., 2015; Shidfar et al., 2015) (as its contents like superoxide anion, hydroxyl radicals and gingerol aid in modulating genetic pathways by activating tumor suppressor gene), renal problems (Kafeshani, 2015), modulating apoptosis (Liu et al., 2012) (terpenoids have been found to induce apoptosis in endometrial cancer cells through the activation of p53), inhibit vascular endothelial growth factor (Rhode et al. 2007, Rahmani 2014), inflammatory responses (Mueller et al., 2010; Mashhadi et al., 2013; Rahmani, 2014; Riaz et al., 2015), anti-inflammatory (Tjendraputra et al., 2001; Mueller et al., 2010; Mashhadi et al., 2013; Riaz et al., 2015) (such as inhibition of COX) and inhibition of nuclear 
factor кB (Grzanna et al., 2005; Rhode et al., 2007; Mueller et al., 2010; Mashhadi et al., 2013; Rahmani, 2014) properties. Similar to antibiotics, the antimicrobial activity of these compounds depends on type and composition of the spice(s), amount used, type of microorganism, the composition of the food, $\mathrm{pH}$ value and temperature of the environment (Sagdic et al., 2003). Herbs contains thermolabile constituents which requires effective extraction techniques with high yield. Several studies relating to extraction exists to date but none with cold extraction method. This study focuses on yield, yield percentage and the extracts (R, P, L and J) antimicrobial activity against pathogens. This data will also shine light on the myth that food containing ginger has surplus amount of antimicrobial compounds. The aim of the study was to analyze the antimicrobial activity of ginger extract against pathogens.

\section{Materials and Methods}

\subsection{Collection of plant materials, microorganisms and investigation}

Local ginger (along with leaves) and packaged ginger powder were purchased from Morang and Kathmandu respectively. American Type Culture Collection (ATCC) stocks of the bacterial isolates were acquired from Institute of Medicine (IOM), Maharajgunj and National Public Health Laboratory (NPHL), Teku; Kathmandu (Table 1). The study was conducted at Microbiology laboratory, Department of Microbiology, St. Xavier's College, Maitighar, Kathmandu, Nepal during the period of November to December, 2016.

Table 1. Ginger extracts and microorganisms used in the study.

\begin{tabular}{lllll}
\hline \multirow{2}{*}{ Sl No } & \multirow{2}{*}{ Extract } & \multicolumn{3}{c}{ Bacteria } \\
\cline { 3 - 4 } & & Gram positive & Gram negative \\
\hline 1 & $\mathrm{R}$ & S. pneumoniae ATCC 6303, S. aureus ATCC & P. aeruginosa ATCC 27853, E. coli ATCC \\
2 & $\mathrm{P}$ & 25923, MRSA (obtained from NPHL) & 25922, K. pnemoniae ATCC 700603 \\
3 & $\mathrm{~L}$ & & \\
4 & $\mathrm{~J}$ & &
\end{tabular}

\subsection{Extraction of plant material}

The plant materials ( $\mathrm{R}$ and $\mathrm{L}$ ) were washed with clean water and allowed to air dry. The outer covering of tumor was manually peeled off. Both the $\mathrm{R}$ and $\mathrm{L}$ were sliced into small pieces. The materials were placed in a hot air oven for drying at a temperature of $65^{\circ} \mathrm{C}$ for 48 hours. Then the dried samples were minced in a grinder.

\subsection{Extraction}

Weighed $10 \mathrm{~g}$ of R, P and L were placed in separate sterilized conical flask and $250 \mathrm{ml}$ of absolute methanol. All the conical flasks were placed in the shaker incubator at $30^{\circ} \mathrm{C}$ at 160 rounds per minute for four days for cold extraction. After four days of cold extraction, the contents of the flasks were vigorously stirred with a glass rod and the mixture was filtered using Whatmann No. 1 filter paper followed by $0.45 \mu \mathrm{m}$ cellulose membrane filtration. The precipitates were discarded and the filtrate was collected for evaporation. The filtrate was poured in the crucibles, placed at $37^{\circ} \mathrm{C}$ water bath for the evaporation dryness and was monitored for 3 days. Fresh juice extract (J) was also acquired from the ginger using sterile mortar and pestle. These recovered extract of R, $\mathrm{P}, \mathrm{L}$ and $\mathrm{J}$ were stored in a refrigerator at $4^{\circ} \mathrm{C}$. The yields $\%$ was calculated using the formula:

$$
\text { Yield } \%=\frac{\text { weight of extract }(\mathrm{g}) \times 100}{10(\mathrm{~g})}
$$

\subsection{Sterilization of materials}

The extracts were exposed to ultraviolet rays for 24 hours. The sterility was checked by streaking the extracts on a nutrient agar plate and incubated at $37^{\circ} \mathrm{C}$ for 24 hours (Gautam et al., 2017a; Gautam et al., 2017b; Gautam et al., 2018).

\subsection{Screening the extracts for antibacterial activity}

The antimicrobial activity of different extracts were determined by cup well diffusion method (Gautam et al., 2017a). The bacterial suspension in nutrient broth was tallied with McFarland standard 0.5 and lawn culture of the test organisms were made on the Mueller Hinton agar plates using a sterile cotton swab. The plates were dried for 15 minutes and wells were made using 4mm sterile borer (Gautam et al., 2017a). Using sterile micropipette $10 \mu \mathrm{l}$ extract ( $\mathrm{R}, \mathrm{P}, \mathrm{J}$ and $\mathrm{L}$ ) were introduced into each of the wells along with control (sterile 
distilled water). The plates were incubated at $37^{\circ} \mathrm{C}$ for 24 hours (Gautam et al., 2017a; Gautam et al., 2017b; Gautam and Adhikari, 2018a; Gautam and Adhikari, 2018b; Gautam et al., 2018; Gautam et al., 2019). The antimicrobial activity was evaluated by measuring the diameter of zones of inhibition (mm).

\subsection{Quality control}

A sample was triplicated and was repeated 4 times in an interval of a week. Purity plating was performed for the media plates and equipment were calibrated. The sterility was checked by streaking the extracts on a nutrient agar plate. ATCC stocks were confirmed using biochemical tests and antibiotic susceptibility tests as per Clinical \& Laboratory Standards Institute (CLSI) guidelines. Statistical analysis was done using SPSS version 19.

\section{Results}

The 3 materials (R, P, L and J) were subjected to cold extraction using methanol. The yield of extract of R, P, L and $\mathrm{J}$ were $1.079 \pm 0.003 \mathrm{~g}, 0.976 \pm 0.016 \mathrm{~g}, 0.817 \pm 0.007 \mathrm{~g}$ and $1.68 \pm 0.199 \mathrm{~g}$ respectively. The percentage yield of R, P, L and $\mathrm{J}$ were $10.79 \pm 0.03 \%, 9.76 \pm 0.16 \%, 8.17 \pm 0.07 \%$ and $16.8 \pm 1.98 \%$ respectively. This data is presented in Table 2.

Table 2. Solvent used for extraction along with yield and yield percentage.

\begin{tabular}{llllll}
\hline Sl No & Initial weight $(\mathbf{g})$ & Extract & Solvent used & Yield $(\mathbf{g})$ & Yield (\%) \\
\hline 1 & & $\mathrm{R}$ & & $1.079 \pm 0.003$ & $10.79 \pm 0.03$ \\
2 & \multirow{2}{*}{10} & $\mathrm{P}$ & Methanol & $0.976 \pm 0.016$ & $9.76 \pm 0.16$ \\
3 & & $\mathrm{~L}$ & & $0.817 \pm 0.007$ & $8.17 \pm 0.07$ \\
4 & & $\mathrm{~J}$ & - & $1.68 \pm 0.199$ & $16.8 \pm 1.98$ \\
\hline
\end{tabular}

The methanol extract of $\mathrm{R}$ was found to be susceptible towards the 5 bacterial isolates except for $P$. aeruginosa. The methanol extract of $\mathrm{P}$ was found to be susceptible to E. coli, S. aureus and MRSA. The methanol extract of L was found to be susceptible to K. pneumonia, S. aureus and MRSA. All 6 bacterial isolates were found to be resistant towards $\mathrm{J}$. The data is presented in Table 3 and Figure 1 and 2.

Table 3. Antimicrobial effect of the extracts against the pathogens.

\begin{tabular}{lllccl}
\hline \multirow{2}{*}{ SI No } & \multirow{2}{*}{ Isolates } & \multicolumn{4}{c}{ Zone of inhibition (ZOI) of extracts } \\
\cline { 3 - 6 } & & $\mathbf{P}$ & $\mathbf{R}$ & $\mathbf{L}$ & J \\
\hline 1 & S. pneumoniae & - & + & - & - \\
2 & P. aeruginosa & - & - & - & - \\
3 & K. pneumoniae & - & ++ & + & - \\
4 & E. coli & + & ++ & - & - \\
5 & S. aureus & ++ & +++ & ++ & - \\
6 & MRSA & + & ++ & ++ & \\
\hline
\end{tabular}

$+++=$ ZOI greater than $20 \mathrm{~mm},++=$ ZOI $10-20 \mathrm{~mm},+=$ ZOI less than $10 \mathrm{~mm},-=$ resistant

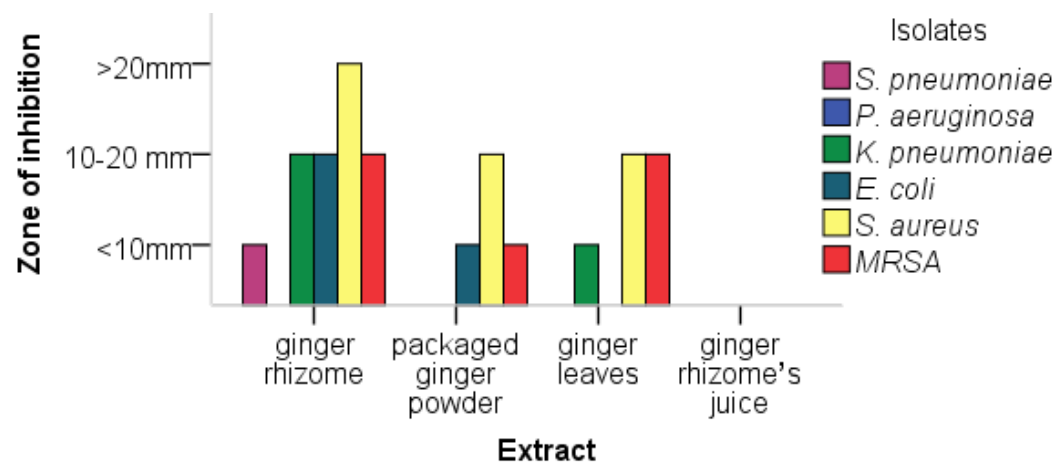

Figure 1. Antimicrobial effect with ZOI of the extracts (R, P and L) and J against pathogens. 


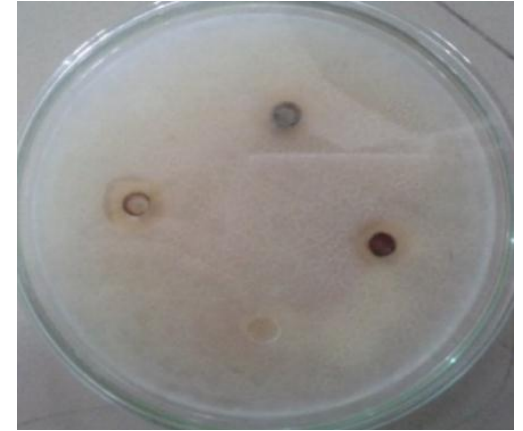

Figure 2. Antimicrobial activity screening against MRSA.

Ginger extracts R, P, L were potent against MRSA while MRSA is resistant towards J.

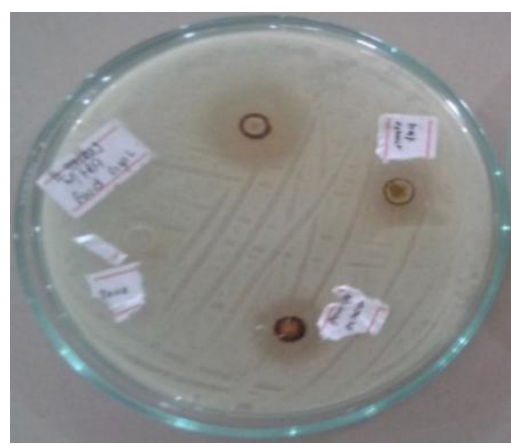

Figure 3. Antimicrobial activity screening against $S$. aureus.

Ginger extracts R, P, L were potent against $S$. aureus while $S$. aureus is resistant towards J.

\section{Discussion}

The yield of an extract of R, P, L and J were $1.079 \pm 0.003 \mathrm{~g}, 0.976 \pm 0.016 \mathrm{~g}, 0.817 \pm 0.007 \mathrm{~g}$ and $1.68 \pm 0.199$ $\mathrm{g}$ respectively. The percentage yield of T, P, L and $\mathrm{J}$ were $10.79 \pm 0.03 \%, 9.76 \pm 0.16 \%, 8.17 \pm 0.07 \%$ and $16.8 \pm 1.98 \%$ respectively (Table 2 ). The methanol extract of $\mathrm{R}$ was found to be susceptible towards the 5 bacterial isolates except for P. aeruginosa (Figures 1-3). The methanol extract of $\mathrm{P}$ was found to be susceptible to E. coli, S. aureus and MRSA (Figures 1-3). The methanol extract of L was found to be susceptible to $K$. pneumonia, S. aureus and MRSA (Figures 1-3). All 6 bacterial isolates were found to be resistant towards J (Table 3 and Figure 1-3). The results (Table 3 and Figures 1-3) indicated that extracts (R, P and L) of ginger have antibacterial activity with a variable degree of susceptibility against the isolates. Ginger extracts (R, P, L and $\mathrm{J}$ ) did not show response towards $P$. aeruginosa. The antibacterial activities of the extracts might be due to the compounds like flavonoids, volatile oil, dissolved organic solvents like sesquiterpenes (Malu et al., 2009; Rahmani, 2014; Riaz et al., 2015). The results of this study harmonize with the results of Malu et al. (2008) which also reached the conclusion, where aqueous extract didn't exhibit the antimicrobial effect. The study of this result coincides with the study of Riaz et al. (2015) where methanol extract was sensitive towards $S$. aureus and $E$. coli. Fresh ginger juice did not show its activity towards the selected microorganisms. This might be due to the high content of water and scanty concentration of antimicrobial compounds in the extract. Phytochemical with the antimicrobial property is more concentrated in the root than in the leaves as the nutrients might get accumulated there (Pandotra et al., 2015). The composition of a ginger or other herbal products varies according to nutrients available (Pandotra et al., 2015; Gautam et al., 2018), soil composition (Pandotra et al., 2015), stage of development of the plant material (Pandotra et al., 2015), climate and the state of rhizomes either dry or fresh (Elvin-Lewis, 2001). The component of the extract may bind to the other components of the glassware or equipment and even prevent biofilm formation (Quave et al., 2008; Sandasi et al., 2010). Based on Table 3 and Figure 1-3, it is clear that ginger used in meals, ginger ale, tea etc. contains a low concentration of the antimicrobial compounds but when cooked with alcoholic beverages like wine, rum, beer etc. the ethanol contained in them may dissolve these antimicrobial compounds (Auta et al., 2011). Using appropriate techniques the phytochemicals can be extracted from the ginger and can be used in herbal products like medicines (Sloand and Vessey, 2001; El-Ghorab et al., 2010) (toothpaste, allopathic etc.). Extract of herbal medicines are subject to degradation and decomposition on storage due to the volatile nature of the active ingredients (El-Mahmood and Doughari, 2008) and can even require preservatives (Gautam et al., 2017a; Gautam et al., 2017b) to increase the longer shelf-life.

\section{Conclusions}

Thermolabile components of the ginger can be extracted through this technique. The ginger leaves also have antimicrobial compounds. The extracts show antimicrobial property only when the extracts are concentrated $(\mathrm{T}$, $\mathrm{P}, \mathrm{L})$.

\section{Acknowledgements}

The authors are thankful to Mr. Sudhakar Pant, HOD, Department of Microbiology, St. Xavier's College for providing the laboratory facilities. The authors are also thankful to Ms. Ganga Shrestha and Mr. Prakash Manandhar. 
Conflict of interest

None to declare.

\section{References}

Auta K, A Galadima, J Bassey, O Olowoniyi, O Moses and A Yako, 2011. Antimicrobial properties of the ethanolic extracts of Zingiber officinale (Ginger) on Escherichia coli and Pseudomonas aeruginosa. Res. J. Biolog. Sci., 6: 37-39.

Chan E, Y Lim, L Wong, F Lianto, S Wong, K Lim, C Joe and T Lim, 2008. Antioxidant and tyrosinase inhibition properties of leaves and rhizomes of ginger species. Food Chem., 109: 477-483.

El-Ghorab AH, M Nauman, FM Anjum, S Hussain and M Nadeem, 2010. A comparative study on chemical composition and antioxidant activity of ginger (Zingiber officinale) and cumin (Cuminum cyminum). J. Agri. Food Chem., 58: 8231-8237.

El-Mahmood A and J Doughari, 2008. Phytochemical screening and antibacterial evaluation of the leaf and root extracts of Cassia alata Linn. African J. Pharm. Pharmacol., 2: 124-129.

Elvin-Lewis M, 2001. Should we be concerned about herbal remedies. J. Ethnopharm., 75: 141-164.

Gautam B and R Adhikari, 2018a. Association of antibiotic and heavy metal resistant bacteria screened from wastewater. Int. J. Env. 7: 28-40.

Gautam B and R Adhikari, 2018b. Comparison of membrane filtration and replica plate technique to detect fecal coliform. Med. J. Shree Birendra Hos., 17: 25-31.

Gautam B, L Aryal, S Adhikari, M Rana, A Rajbhanshi, S Ghale and R Adhikari, 2018. Isolation of bacteriophage from Guheswori sewage treatment plant capable of infecting pathogens. Res. Pharm.Heal. Sci., 4: 465-470.

Gautam B, E Dongol and A Shrestha, 2017a. In-vitro antimicrobial activity of different toothpastes. J. Kathmandu Med. Coll., 13: 52 - 58.

Gautam B, S Pokhrel, S Aryal and A Basnet, 2017b. Efficacy of toothpaste in reducing micro-flora isolated from toothbrush. Kathmandu Univ. J. Sci. Eng.Tech., 13: 71 - 78.

Gautam B, A Rajbhanshi and R Adhikari, 2019. Bacterial load reduction in Guheswori Sewage treatment plant, Kathmandu, Nepal. J. Coll. Med. Sci., 15: 40-44.

Grzanna R, L Lindmark and CG Frondoza, 2005. Ginger-an herbal medicinal product with broad antiinflammatory actions. J. Med. Food, 8: 125-132.

Kafeshani M, 2015. Ginger, micro-inflammation and kidney disease. Nutrition, 31: 703-707.

Liu Y, RJ Whelan, BR Pattnaik, K Ludwig, E Subudhi, H Rowland, N Claussen, N Zucker, S Uppal and DM Kushner, 2012. Terpenoids from Zingiber officinale (Ginger) induce apoptosis in endometrial cancer cells through the activation of p53. PloS one, 7: e53178.

Mahluji S, VE Attari, M Mobasseri, L Payahoo, A Ostadrahimi and SE Golzari, 2013. Effects of ginger (Zingiber officinale) on plasma glucose level, HbA1c and insulin sensitivity in type 2 diabetic patients. Int. J. Food Sci. Nutr., 64: 682-686.

Malu S, G Obochi, E Tawo and B Nyong, 2009. Antibacterial activity and medicinal properties of ginger (Zingiber officinale). Glob. J. Pure App. Sci., 15: 365-368.

Mashhadi NS, R Ghiasvand, G Askari, M Hariri, L Darvishi and MR Mofid, 2013. Anti-oxidative and antiinflammatory effects of ginger in health and physical activity: review of current evidence. Int. J. Prev. Med., 4: S36.

Mueller M, S Hobiger and A Jungbauer, 2010. Anti-inflammatory activity of extracts from fruits, herbs and spices. Food Chem., 122: 987-996.

Pandotra P, B Viz, G Ram, AP Gupta and S Gupta, 2015. Multi-elemental profiling and chemo-metric validation revealed nutritional qualities of Zingiber officinale. Ecotoxicol. Env. Saf., 114: 222-231.

Quave CL, LR Plano, T Pantuso and BC Bennett, 2008. Effects of extracts from Italian medicinal plants on planktonic growth, biofilm formation and adherence of methicillin-resistant Staphylococcus aureus. J. Ethnopharmacol., 118: 418-428.

Rahmani AH, 2014. Active ingredients of ginger as potential candidates in the prevention and treatment of diseases via modulation of biological activities. Int. J. Physiol., Pathophysiol. Pharmacol., 6: 125.

Rhode J, S Fogoros, S Zick, H Wahl, KA Griffith, J Huang and JR Liu, 2007. Ginger inhibits cell growth and modulates angiogenic factors in ovarian cancer cells. BMC Complem. Alt. Med., 7: 44.

Riaz H, A Begum, SA Raza, ZMUD Khan, H Yousaf and A Tariq, 2015. Antimicrobial property and phytochemical study of ginger found in local area of Punjab, Pakistan. 
Sagdic O, A Karahan, M Ozcan and G Ozkan, 2003. Note: effect of some spice extracts on bacterial inhibition. Food Sci. Tech. Int., 9: 353-358.

Sandasi M, C Leonard and A Viljoen, 2010. The in vitro antibiofilm activity of selected culinary herbs and medicinal plants against Listeria monocytogenes. Lett. App. Microbiol., 50: 30-35.

Shidfar F, A Rajab, T Rahideh, N Khandouzi, S Hosseini and S Shidfar, 2015. The effect of ginger (Zingiber officinale) on glycemic markers in patients with type 2 diabetes. J. Complem. Integ. Med., 12: 165-170.

Sloand ED and JA Vessey, 2001. Self-medication with common household medicines by young adolescents. Iss. Compre. Pediat.Nurs., 24: 57-67.

Tjendraputra E, VH Tran, D Liu-Brennan, BD Roufogalis and CC Duke, 2001. Effect of ginger constituents and synthetic analogues on cyclooxygenase-2 enzyme in intact cells. Bioorg. Chem., 29: 156-163. 